\title{
Exploring the Production and Experimentation of Indonesian in Indonesian Literature $^{1}$
}

\author{
Risda Nur Widia \\ Universitas Negeri Yogyakarta, J1. Colombo Yogyakarta No.1, Karang Malang, \\ Caturtunggal, Kec. Depok, Kab. Sleman, Daerah Istimewa Yogyakarta (55281) \\ risdanur.2018@student.uny.ac.id
}

\begin{abstract}
This research aims to describe (1) Indonesian in the production of Indonesian literary works; (2) Experimentation of Indonesian in Indonesian literature as a form of language liberation. This research procedure includes (1) the technique of critical reading of literary texts; (2) The analysis used includes the presentation of data and discussion. The results of the study include (1) Indonesian in the production of Indonesian literary works; (2) Experimentation of Indonesian in Indonesian literature as a form of language liberation. This research procedure includes (1) the technique of critical reading of literary texts.
\end{abstract}

Keywords: Production, Experimenting, Literature.

\begin{abstract}
Abstrak
Penelitian ini bertujuan untuk mendeskripsikan (1) Bahasa Indonesia dalam produksi karya sastra Indonesia; (2) Eksperimentasi bahasa Indonesia dalam karya sastra Indonesia sebagai bentuk pembebasan bahasa. Prosedur penelitian ini meliputi (1) teknik pembacaan secara kritis teks sastra; (2) Analisis yang digunakan meliputi penyajian data dan pembahasan. Hasil kajian meliputi (1) Bahasa Indonesia dalam produksi karya sastra Indonesia; (2) Eksperimentasi bahasa Indonesia dalam karya sastra Indonesia sebagai bentuk pembebasan bahasa. Prosedur penelitian ini meliputi (1) teknik pembacaan secara kritis teks sastra.
\end{abstract}

Kata Kunci: Produksi, Eskperimentasi, Sastra

\section{Pendahuluan}

“...masyarakat kita barangkali dalam proses menciptakan akhir sosial dengan menguburkan sosial di balik simulasi sosial"

Jean Baudrillard

In the Shadow of the Silent Majorities, Or the End of Social, and Other Essays, New York, 1983

Perkembangan teknologi informasi dan komunikasi mutakhir telah mempengaruhi berbagai aspek kehidupan sosial, dan telah menimbulkan tantangan serius terhadap berbagai prinsip

\footnotetext{
${ }^{1}$ Paper ini sebelumnya sudah dipresentasikan dalam seminar Bulan Bahasa yang diadakan oleh Universitas Sarjanawiyata Tamansiswa, pada 13 November 2021.
} 
yang membentuk masyarakat, seperti realitas sosial, struktur sosial, sistem sosial, bahkan konsep dan paradigma kebahasaan hari ini. Perubahan ruang informasi dan komunikasi yang terus berkembang membuat manusia modren ikut bergerak juga ke dalamnya. Ditambah lagi efek pandemi Covid-19 yang belum juga selesai melanda dunia, akhirnya menciptakan ruang-ruang sosial baru yang berhasil mengubah tatanan hidup di ranah epistimologi pemikiran manusia.

Internet, sebelum wabah pandemi Covid-19, adalah satu kebutuhan sekunder yang tidak wajib dimiliki oleh setiap orang. Bagi kelas sosial tertentu, internet bahkan tidak harus ada. Akan tetapi pandemi Covid-19 datang, internet pun menjadi kebutuhan yang tidak bisa terelakkan oleh masyarakat dalam lapis kelas social apapun. Dari sini saja kita sudah merasakan, bagaimana konsep mengenai kebutuhan bertambah karena situasi ruang yang berubah. Bahkan jika kita melihat lebih jauh dalam 10 tahun terakhir, sebelum pandemi datang, Friendster, facebook, twitter, telah merenggut ruang interaksi langsung manusia di masyarakat.

Manusia diseret dalam algoritma, big data, sekularisme meta data yang diciptakan oleh produsen penyedia layanan komunikasi (capitalism cayber). Manusia akhirnya hanya hadir sebagai statistik angka, tanpa ada jiwa di dalamnya, sebut Adorno [1]. Media sosial memang sudah semakin riuh sejak 10 tahun terakhir. Berbagai perusahaan penyedia layanan sosial internet terus mengembangkan vitur-viturnya, dan memaksa manusia untuk semakin terperosok dalam kerangka komunikasi tak langsung pada ruang-ruang maya tersebut. Kebahagian dan kesedihan bahkan sudah lama disimulasikan melalui emotic atau stiker. Manusia tidak lagi diberikan kesempatan untuk menyatakan kebutuhan utamnya, perasaannya, hingga ketakutaknnya di hadapan kapitalisme dan rong-rong para pemodal ekonomi pasar bebas.

Perubahan dimensi komunikasi ini akhirnya membentuk suatu kesadaran baru untuk mendorong lahirnya pengetahuan baru (the new of knowlage) mengenai ruang baru yang sangat konsumtif dan pasif tersebut dalam membaca kehidupan bermasyarakat. Kita dapat ambil contoh mengenai sikap individulisme dan nihilisme yang semakin marak di dunia. Pernah terjadi suatu peristiwa viral di China, mengenai seorang anak yang tertabrak, dan tidak seorang pun bersedia menolongnya. Orang-orang malah lebih memilih merekamnya melalui gawai, ketika si anak yang tergeletak di jalan itu tak berdaya, hingga beberapa jam lamanya. Kejadian ini pun memberikan satu pandangan kepada kita, mengenai kehidupan sosial yang tidak lagi baik-baik saja. Ada semacam batas sosial yang tidak ingin membuat semua orang terlibat di dalamnya, serta sistem kerja norma, komunikasi, dan hukam yang bergeser karena situasi ruang sosial yang berubah.

Apabila melihat dari kejadian di atas ini, konsep modrenisme, yang lahir karena tumbuhnya sikap skeptisme, individulisme, dan nihilisme, sejalan dengan apa yang pernah dipaparkan oleh Baudrillard dalam ranah sosial. Baudrillard pernah menyatakan bahwa di ruang-ruang sosial, kita akan terjebak dalam konsep simulasi sosial, yaitu semacam bentuk komunikasi artifisial yang tidak tercipta secara alamiah di sebuah teritorial yang nyata, akan tetapi di sebuah teritori halusinasi yang terbentuk dari bit-bit informasi [2]. Simulasi sosial pada tingkat tertentu dapat mengubah alih relasi sosial yang sesungguhnya (natural 
time-space), ketika ruang waktu virtual (virtual time space) di dalam berbagai media, internet, televisi, mengambil alih ruang sosial yang natural (social time space). Kematian sosial adalah kondisi ketika persepsi kesadaran (bahkan bahwa sadar) dan emosi setiap orang diserap oleh ruang waktu vitual ini, sehiangga tidak tersisa lagi untuk ruang-ruang yang alamiah. Di dalam kematian sosial tersebut, seorang akan meratapi kematian seseorang tokoh maya pada internet (cyber-figure) lebih hebat ketimbang kematian tetangganya sendiri atau orang lain di dekatnya-death of the social. ${ }^{2}$

Dari sini kita bisa memahami, di dalam kematian sosial, setiap orang akan sepenuhnya hidup di dalam ruang sosial artifisial, dan menjalankannya sebagai aktivitas di dalamnya dengan wujud yang artifisial: bermain di dalam komplek permaianan virtual, belanja lewat teleshopping, bertemu dalam teleconference, memuaskan nafsu dalam cybersex, melakukan kejahatan digital (hacker), menolong orang secara virtual, atau menghabiskan waktu di dalam kuis-kuis televisi. Semua tabiat ini adalah bagian dari kontrakdisksi modrenitas yang telah berhasil dikerasiakan oleh ruang-ruang kapitalsime saiber (capitalism cayber) yang mendorong kita untuk semakin konsumtif, hingga abai pada kenyataan di sekitar sendiri yang lebih urgen untuk dilakukan.

Sikap konsumtif, apatis, hingga merasa bodoh amat terhadap kehidupan sosial di sekitar ini, adalah bagian nyata dari kehidupan milenial [4]. Masyarakat milenila sendiri adalah bagian dari kolompok social modren yang paling melek teknologi dibandingkan dengan generasi sebelumnya, yaitu generasi baby Boomer dan X. Mereka dapat berjam-jam terpaku pada alat elektronik mereka berupa handphone atau laptop. Situasi ini membuat generasi milenial cenderung lebih konsumtif dan jarang berinteraksi sosial selain dengan kelompok-kelompok mereka sendiri di dalam jejaring sosial dunia maya tersebut. Mereka adalah generasi yang paling rentan terjebak pada dunia manipulatif dan ilusif teknologi yang bersifat adiktif [4]. Dalam salah satu jejak suara yang pernah dilakukan oleh New York Times tahun 2007 pada masyarakat Amerika umur 17 hingga 30 tahun, ditemukan bahwa tingkat ketidakkepedulian terhadap tunawisma dan lansia di sana sekitar $30 \%$. Hal ini menunjukan bahwa sikap individulaisme dan skeptisme cukup tinggi di Amerika dari masyarakat milenial.

Marx sendiri pernah meramalkan bahwa teknologi (modrenitas) akan menjadikan manusia sebagai budak atas dirinya sendiri [5]. Apabila kita melihat ini, bahwa generasi milenial hingga generasi $\mathrm{Z}$ tampak sudah terjerat pada teknologi yang diciptakannya, konsep "budak" yang telah dipaparkan oleh Marx dahulu telah menjadi kenyataan. Kenikmatan dalam mengguankan teknologi ini telah menciptakan semacam masokisme yang tidak hanya melukai dirinya sendiri, tapi juga orang-orang di sekitarnya. Bila dalam konsep Marxisme, kenikmatan atas teknologi ini disebut sebagai fetisme sosial—di mana teknologi hadir sebagai benda ajaib yang mengerangkeng manusia untuk tinggal di dalamnya lebih lama, hingga lupa pada realitas nyata di sekiatrnya-bahkan pada inti kemanusian itu [5]. Dari kasus-kasus ini kemudian timbul satu pertanyaan bagi kita: Apakah teknologi dan kaum milenial tidak bisa berkembang menjadi sesuatu yang bersifat positif dan bermanfaat? Apakah kau milenial akan sepenuhnya menjadi budak atas 
teknologi yang menenggelamkan diri mereka sendiri pada sikap konsumtif, individualisme, dan skeptis? Apakah manusia milenial tidak bisa menciptakan satu karya seni yang lebih baik dari generasi sebelumya?

Tentu, kaum milenial, memiliki peran sangat penting dalam pertumbuhan bangsa ini. Ada banyak capaian yang telah diraih oleh kaum milenial dalam 10 tahun terakhir. Kita dapat mengingat Greta Thunberg, seorang gadis berumur 17 tahun dari Jerman, yang menyuarakan mengenai pentingnya kesadaran untuk menyelamatkan lingkungan. Ia pun didukung penuh oleh Greenpeace untuk menyuarakan kepeduliannya terhadap lingkungan. Ia bahkan dipersilakan melakukan pidato mengenai hal itu di ata podium siding besar PBB. Dari sini kita bisa melihat bahwa masyarakat generasi setelah baby boomer dan $X$ masih memiliki sikap peduli dan solidaritas yang tinggi. Ia bahkan menjadi agen perubahan untuk dunia. Selain itu kita juga bisa mengingat Greysia Polii dan Apriyani Rahayu yang berjuang di dalam Olimpiade dan meraih mendali emas. Mereka merupakan dua gelintir dari masyarakat milenial yang dapat mengharumkan bangsa dan menjadi agen perubahan.

Persepsi mengenai masyarakat milenial yang konsumtif, individualistik, dan nihil, pada umumnya hanya sebatas mitos semata. Kapilatisme dan kemajuan teknologi tidak seutuhnya merenggut etos sosial dan sikap empatik yang dimiliki oleh masyarakat milenial. Maka dari itu pada pembahasan di bawah ini, saya akan memaparkan peran kaum milenial dalam perkembangan bidang sosial-kesastraan. Selain itu juga saya akan memaparkan mengenai pembaruan-pembaruan artistik, kebahasaan, hingga gerakan kritik seni melalui bahasa dalam karya sastra yang telah dibangun oleh para penulis milenial.

\section{Metode Penelitian}

Penelitian ini berada pada bidang ilmu sastra. Penelitian pada bidang ilmu sastra pada umumnya menggunakan model penelitian kualitatif deskriptif. Sunarto mengemukakan bahwa penelitian kualitatif bertujuan untuk mendeskripsikan dan menganalisis fenomena, peristiwa, aktivitas sosial, sikap, kepercayaan, persepsi, pemikiran orang secara individual maupun kelompok [6]. Sumber data primer penelitian ini adalah buku sastra Puya ke Puya, Burung Kayu, Di Hadapan Rahasia, Mendengarkan Coldplay, Bakat Menggonggong, Agama Apa yang Pantas Bagi Pohon-Pohon?, dan Ibu Susu. Sumber data sekunder seperti buku-buku teori sastra, jurnal ilmiah yang berkaitan dengan pembahasan, esai, serta dokumen-dokumen lain yang berkaitan dengan objek kajian. Data utama penelitian kualitatif adalah kata-kata dan tindakan [6]. Kedua data tersebut menjadi data utama dalam penelitian ini. Kata-kata dan tindakan yang dimaksud adalah kata-kata dan kalimat di dalam buku sastra Puya ke Puya, Burung Kayu, Di Hadapan Rahasia, Mendengarkan Coldplay, Bakat Menggonggong, Agama Apa yang Pantas Bagi Pohon-Pohon?, dan Ibu Susu.

\section{Bahasa Indonesia dalam Produksi Karya Sastra}

Dalam sepuluh tahun terakhir telah banyak lahir penulis muda yang dapat disebut, atau dikelompakkan sebagai manusia milenial. Karya-karya sastra mereka tersebar dan dibaca oleh berbagai kalangan penikmat buku sastra atau sekadar pembaca umum di berbagai tempat. Karya-karya penulis muda ini bahkan meraih berbagai penghargaan 
tingkat nasional, hingga internasional. Mereka tidak kalah dengan para penulis angkatan sebelumnya. Para penulis milenial ini bahkan mempunyai keresahan yang sama peliknya dengan penulis angkatan sebelumnya. Salah satu dari para penulis muda yang dapat sedikit kita singgung di sini misalnya Faisal Oddang.

Faisal Oddang adalah salah satu penulis muda dari Sulawesi yang dalam sepuluh tahun terakhir cukup banyak menarik perhatian di dunia sastra Indonesia. Pada usia yang belum genap 25 tahun, Faisal Oddang telah berhasil merebut penghargaan cerpen terbaik Kompas pada tahun 2014. Ia mengalahkan nama-nama lama, dari para penulis senior, seperti Budi Darma, Seno Gumira Ajidarma, Agos Noor, Sapardi Djoko Damono, dan masih banyak lainnya. Pada usia muda ini juga Faisal Oddang mendapatkan gelar sebagai prosais terbaik majalah Tempo. Bukunya Puya ke Puya mendapatkan penghargaan dari Dewan Kesenian Jakarta. Masih banyak penghargaan lain yang telah diraih oleh Faisal Oddang dalam jagat sastra Indonesia.

Sebagai salah satu penulis muda potensial Indonesia, Faisal Oddang memang sangat tekun menggali lokalitas Sulawesi dalam karya-karyanya. Dalam buku Puya ke Puya, kita akan merasakan tradisi tanah Toraja dengan sakramen pemakannya yang kental. Selain itu juga di dalam buku Puya ke Puya kita akan menemukan degradasi sikap modrenitas dan tabu budaya yang saling silang-melintas di dalam teks-teks Faisal Oddang. Tema-tema lokal yang diangkat oleh Faisal ini tentu adalah bagian dari sikap peduli dan cinta terhadap tanah air. Selain itu tema-tema lokal yang diambil oleh Faisal Oddang ini adalah bagian dari merawat ingatan mengenai sejarah dan pengetahuan masyarakat Bugis di tanah Sulawesi (dan Indonesia).

Di dalam karya Faisalan Oddang, Puya ke Puya, sejarah dan kebudayaan adalah bahan produksi. Faisal Oddang, dengan memanfaatkan dokument sejarah dan budaya, berusaha untuk membaca peran manusia Bugis dalam pembentukan manusia global hari ini di Indonesia. Faisal Oddang mencoba masuk dalam lokalitas sejarah dan kebudayaan yang jauh dari pengetahuan generasinya, kemudian mereproduksi ulang sikap dan moral lokal Bugis itu sebagai wacana dan pengetahuan yang disublimkan dalam alusi kebijakan dan norma masyarakat hari ini di dalam novel tersebut. Bahasa Indonesia modern pun adalah jembatan bagi Faisal Oddang masuk ke wacana lokal Bugis tersebut.

Kita bisa lihat bagaimana Faisal Oddang memanfaatkan bahasa Indonesia modern sebagai bahan produksi karyanya untuk menjabarkan lokalitas yang kompleks tanpa kehilangan otentisitas kebutuhan atas pengertian suatu tradisi.

"Saya akan mengupacarakan kematian Ambe dengan rambu solo paling sempurna dengan 24 kerbau dan seratus babi lebih dalam tiga hari tiga malam. Dan semua kerabat jauh akan diundang, akan saya bangun lantang sebagai pondok dan rumah singgah selama upacara. Saya sudah meniatkan rambu solo dengan tingkat tertinggi dalam aluk pitung sabbu pita ratu pitung pulo, atau adat 7777. Sempurna, Ambe, sempurnalah. Saya akan membayar semuanya, membayar tanah kita yang sebentar lagi menjadi milik orang 
tambang-membayarnya dengan menjadikanmu To Membali

Puang yang setara dengan dewa-dewa di kayangan. [7]”

Bila mengamati potongan dalam novel Puya ke Puya di atas, kita tidak menemukan sesuatu yang janggal. Teks tersebut bahkan tampak biasa saja layaknya teks yang ditulis menggunakan bahasa Indonesia modern dengan sedikit bumbu bahasa lokal yang ada di dalamnya. Akan tetapi bila melihat lebih detail, khususnya ketika kita membaca langsung novel tersebut pada buku fisiknya, kita tidak akan menemukan catatan kaki atas istilahistilah lokal yang terdapat pada teks tersebut. Padahal umumnya kita akan mendapatkan penjelasan mengenai kata atau kalimat lokal yang tidak ditulis dalam bahasa Indonesia. Teks Faisal Oddang di atas, hadir tanpa penjelasan khusus mengenai istilah lokal yang dimasukannya. Akan tetapi kita tetap bisa memahami teks tersebut dengan melihat konteks dan semantiknya dalam kalimat-kalimat lain yang membentuk universt-nya.

Istilah rambu solo misalnya. Kita tidak akan menemukan apa itu pengertian rambu solo secara langsung di dalam teks. Akan tetapi, ketika kita mencoba membaca secara jeli frasa "upacara kematian" sebelumnya di dalam teks tersebut, kita akan memahami konteks pengertian rambu solo sebagai salah satu bentuk upacara memperingati kematian di tanah Toraja. Selain istilah rambu solo, kita menemukan pula istilah lokal lantang pada teks Faisal di atas. Sekali lagi kita bisa meruntutnya secara konteks dan semantik apa pengertian teks tersebut pada kata atau kalimat lain setelahnya. Misalnya kita bisa mengait-silangkan pengertian lantang dengan sebuah "pondok istirahat". Pada istilah To Membali Puang pun kita juga tidak membutuhkan catatan kaki untuk memahaminya. Dengan mencoba merabaraba konteks dan semantik teks tersebut kita akan menemukan pengertian mengenai kedudukan si mayat setelah mati di kayangan setelah menerima upacara rambu solo.

Kemampuan Faisal Oddang dalam mengimplementasikan bahasa Indonesia modern sebagai kekuatan teksnya, mampu menyeret masuk wacana lokal yang bersifat kompleks ke dalamnya. Kecakapan Faisal Oddang dalam memainkan peran bahasa Indonesi dalam narasinya ini sangat menolong pembaca dalam memahami istilah-istilah Bugis yang asing bagi pembaca umum di luar tanah Sulawesi. Novel ini pun menjadi lebih padat tanpa terlalu banyak memainkan catatan kaki sebagai alat penjelas dari teks-teks Faisal Oddang yang asing. Di sinilah kita bisa melihat bagaimana wacana lokal dan bahasa Indonesia saling melengkapi untuk menemui pemakna semantik yang universal bagi seluruh pembaca karyakaryanya di Indonesia.

Oleh sebab itu, apabila kita melihat kasus yang terdapat pada novel Puya ke Puya, kita dapat melihat secara kolektif, bahwa bahasa merupakan indikator dari keberadaan realitas sosial, dan sebagai sesuatu yang terkait antar individu. Dalam bahasalah dunia sosial dikukuhkan dan sekaligus dipelihara. Selain itu juga bahasa menduduki posisi yang penting dalam mengukuhkan sifat objek dari dunia sosial. Melalui bahasa pula dunia sosial yang objektif dan kompleks diinternalisasikan dan direpresentasikan ke dalam kesadaran subjek masyarakat. Hal ini memang berbanding terbalik dengan sikap Tonny Bennet yang mengemukakan karya sastra sebagai bahasa dan tulisan mengambil jarak dari situasi dan kondisi nyata objek produksinya, yaitu kebijakan atas etika dan moral budaya tersebut [8]. 
Akan tetapi karya Faisal Oddang melampaui situasi dan kondisi tersebut untuk memasuki ke situasi dan kondisi yang hidup dalam ruang dan waktu yang bersamaan. Apabila mengutip Eagleton (1980) kekuatan terpenting tulisan adalah bahasa [9], karena dengan bahasa karya sastra dapat mereproduksi dirinya secara terus menerus sesuai dengan kebutuhan zamannya.

Pola yang sama sebenrnya juga dilakukan oleh penulis muda lain, yaitu Niduparas Erlang. Sebagai salah satu penulis muda asal Serang, Niduparas Erlang termasuk sastrawan muda yang produktif. Karya-karyanya termasuk terpenting dalam peta sastra Indonesia. Tahun lalu, Niduparas Erlang menyabet penghargaa sastra bergengsi di Indonesia, yaitu penghargaan Kusala Sastra Khatulistiwa dari bukunya Burung Kayu. Novel Burung Kayu juga sebelemunya mendapatkan penghargaan dari komite Dewan Kesenian Jakarta sebagai novel yang menarik perhatian juri. Seperti halnya Faisal Oddang, Niduparas Erlang mengambil tema lokalitas di dalam karya-karyanya. Pembicaraan mengenai degradasi masyarakat dari tradisionalisme menuju modrenisme menjadi inti pembicaraan Niduparas Erlang. Bahkan Niduparas Erlang menggunakan cara kerja antropolgi untuk menulis karyakaryanya.

Pada novel Burung Kayu ini cara kerja etnograf sangat terasa di dalam teks-teks Niduparas. Ia masuk sebagai pencatat bahasa dan penerjemah bahasa Mentawai yang menjadi latar novelnya. Istilah-istilah lokal Mentawai, yang menjadikan novel ini kaya, dapat dibaca dengan sangat dekat layaknya novel Puya ke Puya karya Faisal Oddang. Niduparas Erlang bahkan bekerja lebih ekstrim dari Faisal Oddang. Para pembaca ditantang untuk menikmati istilah-istilah lokal tersebut tanpa catatan kaki atau rujukan dekat yang dapat ditemukan secara langsung dalam satu paragraf tersebut. Pembaca harus menyusuri bab demi bab terlebih dahulu untuk dapat memaknai secara semantik istilah-istilah lokal yang dimasukan oleh Niduparas Erlang di dalam novelnya Burung Kayu.

Teknik untuk menghilang catatan kaki dalam menjelaskan istilah lokal memang suatu strategi yang baik sebagai penguatan bahasa Indonesia modern. Bahasa Indonesia juga dapat bekerja berdasarkan ekspresinya dalam menyampaikan gagasan dalam bentuk detaildetail yang panjang mengenai satu objek. Misalnya kita dapat lihat pada kutipan novel berikut ini.

"Ia berputar, melingkar, dengan gerak tangan serupa manyang. Daun-daun sura hijau-ungu-merah-oranye yang terselip di luat manik-manik yang mengikat kepalanya, di kulit kayu tarap yang melingkari pinggangnya, juga terselip di gelang lengannya, berkibaran bagai terus saja mengajak roh leluhur menari di lantai tari. Bunga-bunga sepatu di rambutnya seperti menyala. Merah merona. Seperti bunga api di dekatnya.

Di sekitarnya, tujuh sikerai tua bersila dan membentuk sebuah lingkaran sembari menyanyikan lagu-mantra dalam bahasa Sambulang yang hanya dimengerti para moyang. Lonceng-lonceng kecil di tangan mereka berdentang... [11]” 
Dari teks-teks Niduparas di atas, kita menemukan istilah lokal yang sama sekali tidak diberikan penjelasan apa artinya, baik pada catatan kaki, glosarium, atau catatan lainnya di dalam buku. Pembaca memang sengaja diajak untuk menjelajah setiap bab di dalam buku itu secara sabar, hingga menemukan arti dari istilah lokal tersebut melalui diskripsi atau narasi tertentu yang bersifat tidak langsung. Misalnya pada kata mayang, ketika pembaca menyimak bab satu dalam buku tersebut, pembaca tidak menemukan secara langsung apa arti mayang. Namun pada bagian dua novel ini, pembaca akan menemukan diskripsi 'seorang penari dengan gerakan seekor elang yang melayang'. Kita pun segera dapat mulai menyusun simbol pengertian mayang sebagai suatu koreografi dalam sebuah tarian adat di Mentawai.

Duga-dugaan ini kemudian akan semakin diperkuat ketika kita menemukan kata 'sura' dalam kalimat 'Daun-daun sura hijau-ungu-merah-oranye yang terselip di luat manik-manik yang mengikat kepalanya.' Hipogram mayang sebagai suatu koreografi semakin kukuh hadir menyusun makna semantiknya, karena hadirnya 'properti mahkota' dalam seromoni tarian tersebut. Akan tetapi, pembaca masih dihadapankan pada teka-teki mengenai pengertian sura di dalam teks tersebut. Pembaca pun berusaha merujuk pada nomina daun-daun yang merupakan subjek di dalam teks tersebut. Secara abu-abu pembaca mulai memahami sura sebagai salah satu jenis daun di wilayah mentawai yang masih memiliki makna dengan koreografi mayang. Pada bab empatlah kemudian pembaca akan mengetahui pengertian sura sebagai bentuk pengucapan daun "siri" yang lebih dikenal secara luas di Indonesia.

Selain itu masih terdapat istilah lain seperti sikerai yang pemaknannya pun tidak langsung pembaca temukan saat membaca teks tersebut. Pembaca harus mencoba membacannya secara menyeluruh di teks lain, atau bab lain, yang masih memiliki hipogram atas teks tersebut. Hingga pada bab lima, pembaca akan menemukan frasa 'orang pintar'; bagian bab delapan pembaca akan menemukan frasa 'orang berilmu', dan masih banyak pengertian lainnya yang merujuk pada pemaknaan sebagai "dukun". Di sinilah syahdan pembaca bisa mengartikan secara semantik pengertian sikerai sebagai salah satu tetua/dukun/orang pintar di dalam tradisi Mentawai. Dengan teknik penghilangan catatan kaki ini pembaca memang dituntut untuk lebih jeli memahami setiap simbol yang merujuk pada hipogram sebelumnya. Pemaknaan pun baru bisa benar-benar dilakukan ketika potongan-potongan pengertian yang tersebar di berbagai bab tersebut terkumpulkan.

Penghilangan catatan kaki dalam suatu teks (bahasa Indoensia) yang telah berbaur dengan teks-teks lokal memang membuat pembaca kesulitan memahaminya. Akan tetapi dengan penghilangan catatan kaki ini, sekali lagi, fungsi bahasa Indonesia bekerja lebih maksimal. Penulis dapat memainkan deskrispi atau narasi mengenai satu simbol lokal yang direpresentasikan dalam bentuk panjang dan sastrawai dengan bahasa Indonesia modern. Bahasa Indonesia pun akhirnya tidak saja bekerja untuk menjelaskan suatu objek, tapi menisik benang-benang makna yang tersebar dalam potongan-potongan kata, frasa, atau kalimat di berbagai bab di dalam buku Burung Kayu. Dari sinilah unsur penting karya sastra sebagai ekspresi bahasa bekerja dengan optimal. Bahkan apa yang dilakukan oleh Niduparas Erlang ini sangat berlain dengan konsep-konsep formalis Rusia yang 
menganggap bahwa bahasa di dalam karya sastra adalah bahasa yang lain. Novel Burung Kayu menjadikan bahasa Indonesia modern bukan lagi sebagai 'liyan' atau 'the other', melainkan suatu percakapan intens (dialektika) antara pembaca dan teks sastra untuk menemukan pemaknaan dalam gramatikal bahasa Indonesia yang ketat.

Keniscayaaan bahasa sebagai salah satu sistem tanda dan komunikasi di dalam karya sastra acap menjadi kunci untuk menguatkan ekspresi karya sastra itu sendiri. Karena ketika pengalaman sastrawan yang subjektif itu diterjemahkan sebagai bahasa, pengalaman subjektif dan individual itu akan berubah menjadi pengalaman kolektif dan sosial bagi para pembacanya. Syahdan di sinilah kemudian karya sastra tidak saja menjadi teks bagi para penikmatnya. Karya sastra dapat menjadi sebagai 'wacana' terhadap suatu gerakan tertentu di masyarakat. Karya sastra akan semakin hidup dalam dimensi lain yang lebih luas dalam masyarakat umum. Maka sebab itu, Maxis, selalu berusaha menguatkan kekuatan 'wacana' di dalam teks untuk kepentingan politik mereka [9].

Bahasa Indonesia sebagai bagian dari ekspresi estetik karya sastra juga dapat kita temukan dalam beberapa karya puisi Adimas Immanuel. Adimas Immanuel sendiri adalah penulis dari Solo. Ia merupakan salah satu penyair muda yang sangat produktif di jagat sastra Indonesia. Karya-karyanya banyak diterbitkan oleh Gramedia Pustaka dan beberapa kali masuk nominasi Kusala Sastra Khatulistiwa. Selain menulis sebagai sebuah buku, Adimas Immanuel juga aktif mengirimkan karya-karyanya ke sejumlah koran-salah satunya Tempo. Pada buku kumpulan puisinya yang berjudul Di Hadapan Rahasia, pembaca akan menemukan resepsi sastra terhadap karya-karya perupa dunia. Intektekstualitas yang dilakukan oleh Adimas Immanuel dengan bahasa Indonesia modern jauh melompat ke sub displin seni lainnya. Dalam buku puisi Di Hadapan Rahasia Adimas Immanuel tersebut, gambar dan kata saling berkelindan menerjemahkan dirinya menjadi teks-teks naratif.

Salah satu puisi yang dapat pembaca simak, di dalam buku Di Hadapan Rahasia, yang mencoba mengkolaborasikan antara seni rupa (gambar) dan puisi (teks) ada pada judul Taswir. Puisi tersebut adalah sebagai berikut.

"Kautumpahkan biru dan kelabu pada kanvasmu

seperti juru masak menuang susu dan madu

memperkuat aroma hutan di nganga belanga.

Kau sapukan kuas segaris waktu yang lekas seperti jur khotbah memuntahkan ayat-ayat bah Mengubah mau menjadi lembaran-lembaran kalut.

Dan kami akan mengenal kepura-puraanmu.

Kau terus tumpahkan cat, sapukan penat, berharap perasangka bisa memenuhkanmu.

Kau terus mengarsir dan mengalir diri 
tanpa peduli arah datang cahaya matahari.

Kau menyeret kami ke dunia yang prismatis

Membuat kami tersesat dalam rimba warna

dan corak: keyakinan kian kumal dan koyak

\section{Dan dunia akan berpura-pura mengenalmu.[11]"}

Pada puisi berjudul Taswir ini, di bagian kiri bawah teks dalam buku, terdapat sebuah catatan mengenai sumber resepsi si penyair, yaitu lukisan karya Paul Klee berjudul Portait of An Artist. Karya Paul Klee ini merupakan salah satu karya yang cukup penting dalam peta seni rupa dunia. Karya ini terlahir ketika pembantain Yahudi dilakukan secara masif oleh Nazi di bawah pemimpin diktaktor Adolf Hitler. Paul Klee bahkan termasuk salah satu orang yang menjadi korban dalam pembantaian tersebut. Lukisan Paul Klee berjudul Portait of An Artist salah satu bentuk karya rupa beraliran kubisme yang sedikit berbaur dengan konsep-konsep suralis dan ekspersinosme. Pada lukisan tersebut seorang akan melihat satu garis horizontal serta satu garis vertikal yang dicat berwarna emas dan saling bertumpangtindak membetuk sebuah rusuk salib atau (+). Pada garis horizontal dan vertikal yang membentuk symbol salib atau (+) ini, di kedua sisinya, yaitu kanan dan kiri, terdapat dua lingkaran berwarna merah. Dari titik temu garis vertikal dan horizontal, terdapat setengah segitiga yang terpotong hingga ke bawah. Sementara latar bagian belakang lukisan berwarna hitam-kehijaun. Dari seluruh simbol tersebut, si pemandang karya akan melihat sebentuk wajah abstrak.

Lukisan inilah yang coba diekspresikan oleh Adimas Immanuel di dalam karyanya berjudul Taswir dengan bahasa Indonesia modern. Dengan bahasa Indonesia yang tegas, tapi tetap mempertahankan sisi estetiknya, Adimas Immanuel berusaha meresepsi hipogram-hipogram yang sebelumnya adalah gambar di dalam karya Paul Klee berjudul Portait of An Artist tersebut. Misalnya pada kalimat 'Kautumpahkan biru dan kelabu pada kanvasmu', adalah bagian dari latar belakang lukisan Paul Klee. Akan tetapi Adimas Immanuel berusaha untuk menambahkan satu kesan estetik dalam melihat latar belakang warna kanvas Paul Klee dengan baris kalimat 'seperti juru masak yang menuang susu dan madu/memperkuat aroma hutan di nganga belanga'. Pada bagian ini pembaca akan merasakan bagaimana getaran atas warna latar karya Paul Klee yang sangat sulit diartikan. Karena ketika melihat secara detail karya Paul Klee tersebut, kita akan melihat warna hutan, lumut, dan limbah yang tercemar menjadi satu. Ada semacam nuansa "keliaran" yang sulit untuk dijinakan di dalam warna-warna kanvas Paul Klee.

Walter Benjamin, salah satu Filsuf Mazhab Frakfurt dan seorang penikmat karya Paul Klee yang tekun, pernah mengatakan bahwa warna kanvas Paul Klee adalah sisa asap pembakaran manusia Yahudi. Di sini ada semacam kesuraman dan kemuraman atas warna pilihan Paul Klee dalam lukisannya yang berjudul Portait of An Artist. Warna hijau lumut yang berdegradasi dengan warna hijau hutan barangkali dapat kita baca sebagai bagian dari ekspresi rasa duka Paul Klee terhadap orang-orang Yahudi yang menjadi korban pembantaian Nazi. Adimas Immanuel berusaha untuk menerjemahkan itu dalam bahasa 
Indonesia modern yang stabil dan ketat, tanpa menghilang sisi dramatis, kemuraman, serta rasa pedih atas karya Paul Klee tersebut.

Kemudian pada ornamen lukisan, yaitu garis vertikal dan horizontal yang membentuk tanda salib atau (+) di atas kanvas Paul Klee ini, Adimas Immanuel mengekspresikannya dengan kalimat 'kau sapukan kuas segaris waktu yang lekas/seperti juru khotbah memuntahkan ayat-ayat bah'. Kata 'segaris' dan 'waktu' pada puisi Adimas Immanuel secara eksplisit sangat tampak, dan dapat diartikan, dari simbol salib atau (+). Apalagi pada lukisan tersebut terdapat setangah lingkaran dengan warna merah di bagian atas. Akan tetapi yang menjadikan deskripsi sajak Adimas Immanuel ini semakin kuat adalah larik 'seperti juru khotbah memuntahkan ayat-ayat bah' di sini kita menemukan satu ungkapan yang juga diungkapkan oleh Paul Klee dalam karya-karyanya. Dalam lukisan-lukisan Paul Klee sangat kuat menentang rezim Nazi dan agama yang mengenaralisir pembantaian. Otoritas Katolik di Jerman mengizinkan terjadinya pembantai terhadap masyarakat Yahudi. Karena inilah Adorno pernah menyatakan bahwa, "Eropa tenggelam dalam kelambu hitam agama [13]." Ungkapan Adorno ini tentu sejalan dengan semangat gugatan Paul Klee atas kejamnnya Nazi di bawah Hitler. Adimas Immanuel sendiri mengartikan gugatan atas turut campur agama di dalam pembantain ini dengan larik baitnya yang lain pada puisi Taswir, yaitu 'keyakinan kian kumal dan koyak'.

Puisi adalah tubuh dalam seni rupa, kata Salvador Dali. Dari satu ungkapan ini kita dapat merefleksikan bahwa di dalam kanvas kita dapat merasakan karya sastra, dan di dalam kanvas kita dapat merasakan karya seni rupa. Penyair/perupa yang "melihat" sebagai bahasa sebagai skopophiliak, adalah bagian penting dari kebudayaan, atau katakanlah kehidupan, terutama di masa setelah teleskop, kamera, teknologi perupaan lain ditemukan dan zaman yang ditandai oleh, untuk meminjam kata-kata Henri Lefevbre, "gempuran visualisasi" [14]. Contoh utama adalah Gustave Flaubert. Hubungan Flaubert dengan dunia seni rupa tak saya ketahui, tapi hubungannya dengan gairah visual cukup dikenal. Dalam novel Madame Bovary orang memang bisa terpesona atau bingung mengikuti 120 kata yang dipakai Flaubert untuk mendeskripsikan secuil topi si bocah Charles. Emma Bovary sendiri, seperti Fréderic dalam L'Éducation sentimentale, sering terasa dipergunakan pengarangnya sebagai mata yang merekam dan memantulkan objek-objek yang menjejali dunia. Dalam L'Éducation sentimentale malah pembaca seakan-akan menemukan pelbagai tableaux yang tak jelas relevansinya bagi cerita utama, hanya seperti menegaskan bahwa objek-objek itu memang diperlakukan tokohnya sebagai suar (phares) di cakrawala hidupnya. [14]

Pada posisi yang sama Adimas Immanuel memperlakukan karya Paul Klee. Ia melihat dan mencoba untuk masuk ke dalam narasi sastra yang terdapat dalam narasi seni rupa. Dengan menggunakan bahasa Indonesia modern yang baik, Adimas Immanuel berhasil menguarkan teks-teks seni rupa yang sebelumnya bersifat simbolis. Bahasa Indonesia pun bekerja secara maksimal menyampaikan fungsi estetiknya sebagai karya seni. Selain itu juga bahasa Indonesia, bila meminjam terminologi Salvador Dali, adalah 'pintu masuk pertama dalam karya seni.' 
Teknik resepsi sebagai bagian dari produksi karya sastra dan bahasa Indonesia sebagai medium ungkap dapat kita temukan pula pada karya Mario F Lawi. Mario F Lawi adalah salah satu penulis muda asal Kupang yang memiliki identitas kepenyair yang kuat mengenai tradisi Katolik. Dengan puisi-puisinya, Mario F Lawi berhasil meraih penghargaan Academia Award (2014), Taruna Sastra (2015), dan beberapa kali masuk nominas Kusala Sastra Khatulistiwa. Salah satu bukunya yang menjadi capaian estetiknya dalam dunia sastra adalah Mendengarkan Coldplay. Pada buku tersebut pembaca dapat menemukan nunasa persajakan Alkitab dan album band Coldplay.

Coldplay sendiri adalah satu band Amerika yang sangat terkenal dalam beberapa dekade terakhir. Karya musiknya tersebar dan didengarkan oleh berbagai kalangan di belahan dunia. Mario F Lawi sebagai salah satu pendengar pun mencoba meresepsi liriklirik lagu Coldplay dalam puisi-puisinya. Misalnya pada potongan puisi berjudul Yellow berikut ini.

"Tulang dari segala tulang yang menopangmu

Daging dari segala daging yang menyusunmu

Kulit dari segala kulit yang menjahitmu

Telah mahir mencuri rotasi dari sumbu semesta

Susunan malam diam melesap ke dalam hilang

Dan memintak sekadar merumuskan mereka

Ke dalam sejumlah metafora paling cemerlang

Agar diam mereka sekaligus menjelma sebuah

Gerakan menjahui kamus yang menjerumuskan

[15]"

Bila membandingkan puisi berjudul Yellow karya Mario F Lawi di atas dengan lirik lagu Yellow milik band Coldplay, kita tidak akan menemukan nuansa penciptaan yang sama. Akan tetapi jika kita membaca puisi Yellow di atas lahir atas semangat, mitos, dan alusi semangat kekaryaan band Coldplay, kita akan menemukan secara bertahap potonganpotongan intertekstual karya Mario F Lawi dengan judul lagu Coldplay. Yellow, adalah salah satu judul lagu Coldplay di dalam album Parachutes. Lagu ini terinspirasi ketika Chris Martin melihat bintang-bintang saat melakukan rekaman di studio Quadrangle milik Rockfield dekat Monmouth di Wales Selatan. Warna bintang yang tampak kuning dan tersebar di langit mengingatkan Chirs Martin mengenai penciptaan manusia dan alam semesta yang dilakukan Tuhan. Maka pada lirik lagu tersebut berbunyi, "your skin/ oh yeah, your skin and bones/ trun in something beautiful". Chirs Martin menyebutkan lirik tersebut seabagi bagian dari rasa takjubnya terhadap alam semesta dan Tuhan yang begitu Agung.

Pada puisi Yellow karya Mario F Lawi sendiri kita akan menemukan narasi dengan alusi yang sama pada bagian "tulang dari segela tulang yang menopangmu/daging dari segala daging yang menyusunmu/kulit dari segala kulit yang menjahitmu/telah mahir mencuri rotasi dari bumbu semesta”. Hipogram dari lirik lagu Coldplay sebelumnya dibaca 
ulang dan reproduksi kembali menjadi lirik yang estetik dalam bahasa Indonesia modern yang padu oleh Mario F Lawi. Bahkan apabila kita berusaha untuk menjangkau lebih jauh lagi, larik puisi Mario F Lawi ini juga dibangun atas hipogram teks-teks Alkitab, Yesaya, 58:11, yang berbunyi, "Tuhan akan selalu memimpin engkau, akan memuaskan hatimu di tanah yang kering, dan menyegarkan tulang-tulangmu sebagai pengokoh tubuh. Dan engkau akan menjadi sebuah taman yang diari, dan seperti mata air yang tidak pernah kering"

Kemudian di larik berikutnya pada puisi Yellow karya Mario F Lawi, pembaca akan menemukan potongan sajak, "Susunan malam diam melesap ke dalam hilang/ dan memintak sekadar merumuskan merekal ke dalam sejumlah metafora paling cemerlang," yang apabila kita bandingkan dengan lirik Coldplay "Look at the stars/look how thay shin for youl and all the things that you dof' akan sangat berbeda. Akan tetapi apabila kita membaca 'keresahan-merana' aku lirik si penyair dan Chris Martin di dalam lagunya, yang menuntut mereka untuk 'melakukan sesuatu' atas ketekjuban dengan penciptaan dunia dan alam semesta, kita akan menemukan penghubungan intekstualitas yang dilakukan Mario F Lawi dengan lirik lagu Chris Martin pada bagian "dan memintak sekadar merumuskan mereka/ ke dalam sejumlah metafora paling cemerlang;" dengan "look how thay shin for you/ and all the things that you do/" Pada dua bagian ini kita dapat melihat "kecemerlangan Ilahi" yang menuntut "aku lirik" di dalam puisi dan lirik Yellow untuk "melakukan sesutau terpikirkan" (all thing that you do) dan "meminta sekadar merumuskan mereka/ ke dalam sejumlah metafora paling cemerlang".

Bahasa Indonesia, sebagai bagian dari proses produksi karya sastra, tidak hanya mampun menjadi acuan yang terarah pada dunia sosial saja, melainkan ke dunia lain, yang sangat jauh dari kenyataan komunikasi. Dengan kemampuan bahasa Indonesia, sebagai penerjemah 'eskpersi manusia' ini akan menjadi jembatan bagi pembaca untuk keluar dari situasi dan kondisi historis mereka sendiri. Bahasa bahkan akan menjadi 'tubuh baru' dalam pengalaman dan pengetahuan menerjemahkan simbol dan tanda yang sebelumnya tidak terkait dengan situasi tertentu. Jasa psikoanalisa, seperti yang kemudian dikembangkan dalam "semanalisis" Kristeva, adalah menghubungkan kembali bahasa dengan tubuh, mental, dan unsur atas hasrat yang terpendam dan tak disadari manusia. Semula, seperti dikatakan Freud, peradaban bermula semenjak manusia meletakkan bahasa di atas indra lain, seakan-akan bahasa bukan bagian dari proses badani, psikoanalisa mengembalikan peran "yang di bawah" dalam peradaban. Dari praktik psikoanalisisnya, Kristeva menyimpulkan, elemen "yang semiotik", le sémiotique atau dorongan badani itu, ikut membentuk makna bersama-sama bahasa, bersama-sama "yang simbolik". Tapi ada yang penting yang belum dikemukakan Freud maupun Lacan. Bagi Kristeva, Lacandengan Tata Simboliknya-hanya memperhatikan artikulasi yang diskursif, di mana makna bahasa sebagai bangunan simbolik sangat dominan. Lacan, bagi Kristeva, mengabaikan dorongan naluri, melalaikan jouissance dari elemen "yang semiotik", yang terungkap dalam desah napas, intonasi, ritme, patahan kata. Dalam yang nonsense, tak berarti sebuah karya lepas sama sekali dari Tata Simbolik. Selalu ada dari dalamnya yang bisa diidentifikasikan — makna atau bentuk yang kuranglebih stabil dan dikenali bersama - yang membuat karya seni berbeda dari guratan yang mengigau. Surealisme, jika kita mengikuti 
prinsip pendirinya, André Breton, menghendaki sejenis ekspresi otomatis ("sebuah monolog yang diucapkan secepat mungkin, tanpa campur tangan dari kapasitas kritis pikiran"). Tapi dalam praktiknya, Surealis, seperti dalam analisis Kristeva, tak melepaskan diri sama sekali dari "yang simbolik", karena "yang simbolik" adalah bahasa itu sendiri.

\section{Eksperimentasi Bahasa Indonesia dalam Karya Sastra Indonesia Sebagai Bentuk Pembebasan Bahasa}

Eksperimen di dalam sastra sangat diperlukan untuk menunjang perkembangan pencapaian bentuk dan estetika karya. Selain itu juga eksperimen dalam karya sastra dapat menjadi resistensi atas konsep-konsep atau gagasan-gagasan lama yang sudah lebih dahulu mengayomi. Misalnya, di dalam dunia seni rupa, kita pernah mendengar nama Marcel Duchamp. Perupa tersebut, pada tahun 1917, mengirimkan sebuah karya berjudul 'Pispot' kepada panitia The Society of Independent Artist, Inc. di New York, dan mampu merobohkan sikap seni rupa abad ke-20. Pada mulanya Duchamp tidak menggunakan nama aslinya. Ia menggunakan nama samaran, yaitu R. Mutt. Karya itu pun segera ditolak oleh panitia penyelenggara dengan alasan, "meskipun pispot mungkin sebuah objek yang berguna di tempatnya, pameran ini bukan tempat yang cocok; menurut defisininya, ia bukan sebuah karya."

Akan tetapi itulah yang hendak ditumbangkan oleh Duchamp dengan eksperimen karya Pispot. Ia mencoba melahirkan sebuah pardoksal mengenai definis 'karya seni' dan 'bukan karya seni'. Duchamp menghasilkan barang-jadi (ready-made), sebuah tropis, sebagai sebuah rendezvous, seperti yang diutarakan oleh Duchamp. Karena bagi Duchamp, "barang jadi itu adalah tempat berjumpa di mana penonton hadir dan ikut membentuk momen itu, untuk ikut menentukan sebuah momen estetik atau bukan." Ini sebuah geberakan yang dilakukan oleh Duchamp. Selain itu juga Duchamp membuka pintu bagi seni rupa kontemporer Amerika untuk melihat ulang pengertian karya seni. Hingga dua dasawarsa kemudian, ketika peristiwa seni rupa di New York terungkap, si pembuat adalah perupa terkemuka bernama Marcel Duchamp, bukan R.Mutt, publik kritik seni rupa mentasbihkan karya Pispot sebagai karya seni. Panitia The Society of Independent Artist, Inc pun menyatakan karya tersebut sebagai, "angin pengusik karya seni kubisme yang sudah lama mengakar terlalu kuat dalam seni rupa." Dari peristiwa seni rupa di New York ini, kita dapat melihat bagaimana sebuah tradisi dapat berubah karena adanya distraksi dari eksperimentasi karya. Konsep dan wacana mengenai 'karya' yang sebelumnya bersifat 'avant-garde' dengan pengaruh kubisme Prancis dapat digoyahkan dengan bentuk seni minimalis tak berkonsep dari Marcel Duchamp.

Di dalam kazanah sastra Indonesia sendiri, kita pernah memiliki Chairil Anwar dalam peta angkatan sastra tahun 1945. Puisi-puisi Charil Anwar muncul sebagai "suara yang berbeda" di tengah gegap-gempita revolusi Indonesia yang lebih mengutakan selogan, retoritka, dan ajakan-ajakan yang bersifat revolusiner. Di dalam sajak-sajak Charil nyaris tidak pernah ditemukan istitalah/kata, 'keremus', 'ganyang', 'konfrontasi', atau 'militansi' yang saat itu banyak ditemukan pada karya sastra angakatan 1945. Charil Anwar malah sibuk dengan puisi-puisi senitimentilnya untuk mengungkapkan perasaan sepi, duka, patah hati, hingga rasa kecewa menggunakan bahasa sehari-hari. HB Jasssin pun mengatakan 
bahwa, "Charil adalah sang pioner," dan memang yang terjadi kemudian Chairil adalah sang pionir bagi bahasa Indonesia untuk keluar dari kungkungan politik dan propaganda Jepang dalam semangat revolusi politik praktis. Tanpa Chairil Anwar, kita pun mungkin tidak akan pernah bisa membaca puisi-puisi Sapardi Djoko Damono, Joko Pinurbo, hingga Aan Mansyur. Puisi-puisi mereka secara ketat menggunakan bahasa Indonesia modern sehari-hari, tanpa terlalu banyak mencoba memainkannya menjadi "sesutu yang gelap" dan "sulit dipahami" seperti tradisi para penyair sebelumnya. Karya-karya mereka lebih bersikap sebagai 'karya universal' yang dapat dibaca setiap golongan tanpa bekal ilmu sastra sekali pun. Sikap untuk membebaskan Bahasa Indonesia dari belenggu ekslusifitas para penyair ini, membuat bahasa Indonesia lebih dinamis untuk tumbuh dan bekembang.

Di ranah prosa Indonesia, kita memiliki beberapa penulis muda potensial, yang menulis dengan baik menggunakan bahasa Indonesia modern, dan melakukan eksperimentasi di dalam karya sastra dengan memanfaatkan bahasa. Yang pertama, kita bisa menyebut nama Dea Anugrah. Dea Anugrah adalah seorang penulis asal Bangka yang cukup produktif. Ia banyak menulis untuk koran Tempo dan beberapa kali menerbitkan buku. Salah satu bukunya yang sangat berpengaruh, serta memberikan warna dalam peta sastra Indonesia adalah buku kumpulan cerpen, "Bakat Menggonggong". Buku kumpulan cerpen Dea Anugarh ini telah mendapatkan pengargaan dari Pusat Bahasa. Selain itu juga buku ini memberikan gebrakan bagi karya-karya Indonesia yang pada umumnya ditulis secara literer tanpa ada permaian bahasa yang baik.

Pada buku "Bakat Menggonggong" ini, pembaca misalnya dapat menemukan satu eksperimen bentuk repetisi di dalam cerpen "Penembak Jitu". Teknik repetisi itu adalah sebagai berikut.

"Sebidang rawa. Sebuah bukit di sisi timur sebidang rawa. Semak-semak di sisi timur sebidang rawa. Dua gerumbul rapat semak beri hutan sebidang rawa. Sebuah lubang hitam sebidang rawa.[16]"

Teknik repetisi di dalam paragraf di atas, menempatkan kata 'sebidang rawa' sebagai objek di dalam kalimat. Objek 'sebidang rawa' ini kemudian berulang pada kalimat-kalimat lainnya yang berada sesudah kalimat sebelumnya. Model penggambaran seperti ini pun memberikan cara baru bagi pembaca untuk menyusun detail latar di dalam karya sastra. Pembaca tidak lagi disodorkan pada bentuk konvesional latar yang biasanya hanya ditulis secara linier dengan mempertahankan 'bentuk visul' suatu dioaram yang inginkan dijelaskan, dan mendeskripsikannya secara konvensional. Dea Anugrah, dengan teknik 'repetisi' ini malah mampu memberikan suspensi dalam teks-teksnya untuk menikmati latar suatu cerita dengan penekanan frasa "sebuah rawa". Selain itu repetisi yang biasanya dianggap sebagai bagian dari ketidakefektifan kalimat, di dalam teks-teks Dea Anugrah, menjadi sangat berarti bagi permainan plot pada ceritanya.

Pada cerpennya yang lain, pembaca juga akan menemukan teknik repetisi ini, misalnya pada cerpen berjudul "Kisah Sedih Kontemporer" sebagai berikut. 
"Rik, temanku, adalah penulis yang bagus dan manusia yang baik tetapi tolol. Ia adalah penulis yang bagus dan manusia yang baik tetapi tolol dan akhirnya mati karena paru-parunya berair. Ia adalah penulis yang bagus dan manusia yang baik tetapi tolol dan akhirnya mati karena paru-parunya berair, dua tahun lebih cepat dari perkiraanku. Ia adalah penulis yang bagus dan manusia yang baik tetapi tolol dan akhirnya mati karena paru-parunya berair, dua tahun lebih cepat dari perkiraanku, tanpa pernah dipedulikan orang lain [16]."

Cerpen "Kisah Sedih Kontemporer" ini juga menggunakan repetisi sebagai bentuk pembangun supensi penggambaran karakter tokohnya. Dea Anugrah dengan memanfaatkan konjungsi korelatif mendeskripsikan tokoh Rik sebagai "penulis bagus", tapi merupakan "manusia tolol." Selain menggunakan konjungsi korelatif, Dea Anugrah juga menggunakan konjungsi “aditif” untuk menggambarkan keadaan Rik yang mati karena terkena paru-paru basah. Permainan repetisi ini memberikan semacam penyegaran terhadap teks-teks sastra secara umum yang ditulis secara gramatikal. Dengan perulangan permaianan rima dan konjungsi ini, Dea Anugrah mampu memberikan kesan baru dalam narasis penggambaran karakter di dalam karya sastra Indoensia. Tidak heran, Nirwan Dewanto menyebut karyakarya Dea Anugrah sebagai, "karya-karya penting bagi Indonesia," karena Dea berusaha mendobrak arus narasi yang bersifat "efektif" dan "tidak efektif" di dalam karya sastra.

Modrenisme memang telah berhasil memberikan ruang yang luas bagi karya seni dan sastra untuk tumbuh. Tidak hayal, Habermas mengatakan, bahwa "modrenisme adalah langit luas yang mampu menampung pikiran umat manusia [17]". Konsep bahwa modrenisme tidak memberikan batas ruang tertentu mengenai konsep dan definisi suatu pengetahuan membuat karya seni dapat bergerak dengan fleksibel. Karya sastra, sebagai salah satu karya seni yang memanfaatkan bahasa, ikut berkembang pesat. Teks-teks di dalam karya sastra tidak lagi terkungkung berdasarkan fungsinya. Teks-teks tersebut dapat bergerak, menisik, hingga mengeskpersinya bentuknya melalui kalimat-kalimat lugas di dalam suatu karya. Tidak pelak Takdir Alisjabahana mangatakan bahwa modrenisme, "telah memabangunkan mereka dari mimpi nikmat." [18] Mimpi yang nikmati di sini adalah pandangan tradisionalisme yang begitu teratur dan monoton.

Selain Dea Anugerah, sastra Indonesia juga memiliki pengarang muda yang baik dan layak disebut sebagai pionir, yaitu Eko Triono. Eko Triono adalah salah satu pengarang asal Cilacap. Ia telah banyak melahirkan karya bermutu di Kompas, Jawa Pos, Tempo, dan media lainnya. Eko Triono meraih penghargaan sebagai cerpenis terbaik Balai Bahasa Jogja pada tahun 2017 dengan bukunya yang berjudul, "Agama Apa yang Pantas Bagi PohonPohon?" Karya-karya Eko Triono disebut sebagai, "ombak yang mengusik tebing karang yang kokoh" oleh Tia Setiadi [19], karena upayanya untuk mengganggung sistem tata bahasa Indonesia. Kemampuan Eko Triono untuk "mengangkangi bahasa Indonesia" 
sebagai bahasa formal sangat tampak misalnya pada cerpen berjudul, "Dia, Kamu, Feng Menglong, 25, dan 21." Pada cerpen tersebut Eko Triono menghilangkan tanda kutip dua (“") dalam percakapan cerpen-cerpennya.

"Para lelaki menginginkan itu dari perempuan, mereka tidak melihat jiwa kami, tapi bagian tubuh kami.

Mungkin itu kekasihmu, balas pemuda 25 tahun, aku hanya ingin membuatmu terhibur hingga kereta ini berhenti.

Gadis itu menatapnya, benar tidak ingin?

Tidak juga, maksudku, kata pemuda 25 tahun, aku sudah membawa-bawa Feng Menglong, memalsu cerita atas namanya, meminjam tujuh orang pencerita yang...

Yang mengarah pada titik yang sama?

Maksudmu?

Titik begini? Tanya gadis 21 tahun.

Kamu terdiam cukup lama, sehingga dia menarik sandaran darimu. Dia bekata lirij apa yang dimaksud dengan kata: begini, oleh gadis 21 tahun dalam ceritamu tersebut? [20]"

Tidak ada satu pun tanda kutip dua (“") dalam percakapan antara pemuda umur 25 dengan perempuan umur 21. Teks-teks percakapan itu dibiarkan bebas begitu saja tanpa penyekat yang difungsikan untuk menyatakan kalimat secara langsung. Karena, apabila melihat aturan umum bahasa Indonesia, tanda kutip dua ("') dalam suatu tulisan digunakan untuk menyatakan suatu argument, atau pernyataan langsung seseorang. Akan tetapi, Eko Triono menghilangkan itu. Ia melanggar kaidah bahasa Indonesia yang baik dan benar sesuai dengan pedoman Kamus Umum Bahasa Indonesia. Apakah Eko Triono salah dalam melakukan hal itu?

Apabila ditinjau dengan ilmu kebahasaan tentu salah. Hanya saja apabila tujuan penghilangan tanda kutip dua ("') pada kalimat-kalimat percakapan langsung di dalam teks tersebut, adalah bagian dari upaya pembebasan bahasa melalui jalur seni, apa yang dilakukan oleh Eko Triono dapat disebut sebagai "suatu ikhtiar". Karena, kita paham, bahasa tidak akan pernah lepas dengan politik kekuasaan. Kita bisa mengingat bagaimana pergeseran makna sebutan "bung" di era revolusi tahun 1945, adalah sapaan bagi orangorang yang menganggap dirinya yang mendukung revolusi Indonesia. Akan tetapi kata "bung" mengalami distorsi makna setelah kudeta politik 30 September 1965. Sapaan "bung" lebih dikaitkan sebagai kelompok orang-orang yang memiliki afiliasi politik kiri (PKI). Ikthir yang dilakukan Eko Triono untuk membebaskan tata bahasa dari kerangka politik praktis Badan Bahasa ini mendapat sambutan hangat, "andaikan bahasa adalah air, maka bahasa cerpen Eko adalah ombak yang ganas,” oleh Tia Setiadi [19]. 
Penghilangan tanda kutip dua ini juga mengingatkan kita pada aliran filsafat fenomenologi Hursserl yang menempatkan "kesadaran" dan "ketidaksadaran" objek sebagai bagian utama kajiannya. Husserl berusaha untuk menerangkan pengetahuan manusia mempunyai "rechtsanspruch auf gegestanliekeit", artinya kita mengerti dan dalam pengertian itu kita dapat mengatakan bahwa pengertian itu mempunyai objek dan tidak sekaligus. Objek sendiri selalu ditandai dengan bahasa, termasuk pengetahun dan kesadaran. Untuk mencapai pengertian sempurna mengenai kesadaran, manusia harus berani meninggalkan pendiriannya yang biasa itu. Selain itu juga harus ada reduksi "Phanomenologische Reduktion" dari pengalaman-pengalaman indrawi yang direpesentasikan melalui bahasa "erlebnisse".

Selain itu Husserl juga menyatakan sikapnya bahwa kesadaran merupakan bagian dari ketidaksadaran. Manusia yang terikat pada "realitas" akan "hanyut" tanpa disadarinya. Percakapan-percakapan akan menjadi kabur, bercampur dengan alusi mimpi, imajinasi, dan bayang-bayang yang berkelindan tanpa ada jeda "uneklammnern". Jadi tidak ada lagi penundaan yang dilakukan oleh "tata bahasa" untuk mengekang "bahasa" sebagai sesuatu yang liar, spontan, dan kabur di dalam mental kesadaran manusia yang terus terombangambing. Dari sini kita dapat melihat bagaiaman kesadara mengekang bahasa yang sebelumnya liar dan bekeraja di dalam "ketidaksadaran". Pengekangan ini menciptakan semacam reduksi untuk menusia sejenak mengambil jeda atas pikirannya sendiri yang sebenarnya terus bergerak. Penghapusan tanda kutip dua ("') pada cerpen Eko Triono ini adalah upaya yang dilakukan oleh Eko Triono sejenak melepaskan gangguan atas bahasa Indonesia yang dibebani aturan sejak kelahirannya sebagai alat komunikasi.

Teknik aliran "ketidaksadaran" sebagai upaya membebaskan bahasa Indonesia juga dilakukan oleh Rio Johan. Rio Johan sendiri merupakan penulis berbakat Indonesia yang telah mearaih banyak penghargaan. Salah satu penghargaan bergengsi yang pernah didapatkannya adalah meraih Kusala Sastra Khatulistiwa pada tahun 2018 bagi penulis muda berbakat pada bukunya Ibu Susu. Novel ini termasuk salah satu karya yang tidak boleh dilewatkan untuk dibaca, karena menyodorkan satu wacana lain mengenai bentuk dan pencapaian estetik di dalam khazanah sastra Indonesia. Pada novel Ibu Susu, pembaca akan menjumpai banyak sekali bagian paragraf yang terdiri hanya satu kalimat. Pembaca akan dibawa pada deskripsi panjang, hingga dua atau tiga halaman, yang sama sekali tidak diberikan jeda berupa tanda titik (.), koma (,), hingga titik dua koma (;).

Salah satu penggalan paragraf yang penelaah kutip adalah sebagai berikut.

“...begitulah para menteri urusan batu sekalipun mereka beranjak dengan jumlah awalan dan keunggulan yang jauh dibandingkan dua kelompok lainnya pada akhir minggu ketiga bulan Panipet pasukan batu yang didapat menurun drastis padahal angka yang perlu dikejar sekadar secuil deben lagi dari masingmasing batu penyebabnya tentu saja semakin banyak pedagangan yang culas dan cerdik 
menyelundupkan begitu juga yang malas melancong dan menyimpan batu-batuan mereka sampai perkara perminataan Perempuan Iksa beres dan para menteri yang sempat berpikir tak perlu repot-repot menurunkan tambahan budakbudak pengumpul ke lombong-lombong di penjuru negeri terpaksa mengambil langkah lain maka didatangkanlah secara besar-besaran batu merah hitam dan abu-abu dari Shellal Silsileh Swenett maupun Setet kuarasa dari bukit merah di tepian timur sungai beberapa lagi dari perbukitan di selatan delta sungai dari gemurun keramat di timur dari gurun di tanah Kush dari tambang-tambang Idahet juga dari lombonglombong kecil seperti Tura atau kuil Ptah tahap dadakan ini meski berjalan begitu lambatnya pada akhirnya mampu juga memenuhi hampir semua tuntutan batu mineral dalam daftar...[21]"

Teks di atas tidak saya kutip sepenuhnya. Akan tetapi cukup dari teks ini saja, kita dapat melihat tidak ada sama sekali tanda titik (.), koma (,), atau titik dua koma (;) yang biasanya digunakan seseorang penulis untuk memberikan jeda pada kalimatnya. Teks-teks Rio Johan mengalir layaknya pikiran yang tidak sadar. Ini sejalan dengan konsep ketidaksadar Hussrel bahwa, "manusia yang terikat pada "realitas" akan "hanyut" tanpa disadarinya. Percakapan-percakapan akan menjadi kabur, bercampur dengan alusi mimpi, imajinasi, dan bayang-bayang yang berkelindan tanpa ada jeda "uneklammnern". Jadi tidak ada lagi penundaan yang dilakukan oleh "tata bahasa" untuk mengekang "bahasa" sebagai sesuatu yang liar, spontan, dan kabur di dalam mental kesadaran manusia yang terus terombang-ambing."

Ketidaksadar selalu bersifat pararlel. [22] Hal ini terjadi karena sistem pikiran manusia yang bekerja cepat dan membuat "keos" dalam menentukan subjek dan objek, sebab kesadaran dan ketidaksadaran merupakan dua hal yang wajib ada di dalam otak. Kesadaran adalah pintu gerbang ke dalam sumber pengetahuan yang tidak disadari [22]. Kesadaran dianalogikan sebagai tombol perintah (global search) dalam sebuah komputer, karena dengan menekan tombol itu, maka dokument (bahasa) apapun dapat ditemukan. Akan tetapi bahasa adalah pengetahuan yang tidak pernah disadari, bila meminjam konsep Hussrel. Manusia tidak pernah sadar kapan dirinya memahami bahasa secara utuh. Mereka tiba-tiba dapat menguasainya dengan alamiah. Cuma apa yang dianggap oleh Husserl sebagai yang "alamiah" mengenai bahasa ini dikritik juga oleh Maurice Merleau Ponty. Ia menyatakan bahwa bahasa adalah hasil "hibriditas antar manusia". Jadi apa yang dimaksud oleh Ponty di sini adalah hasil rekasa ketidaksadaran manusia dalam menyatakan suatu objek. Ada kepentingan yang direpsentasikan melalui simbol-simbol ketidaksadaran, dan bahasa ada simbol-simbol yang bekerja secara struktural tersebut. 
Maka ada semacam dualisme yang menanungi sistem kerja pengetahuan manusia mengenai bahasa. Kesadaran dan ketidaksadaran bekerja secara melompat-lompat (nonlinear) dan saling melengkapi. Mimpi dan kenyataan berbaur, ungkap Picasso. Pada teksteks Rio Johan ini kita pun dapat merasakan di mana subjek dan predikiat berbaur menjadi satu gramatikal yang kacau dan saling bertumpukan-bahkan bertubrukan satu dengan yang lain. Teks-teks Rio Johan bekerja secara non-linier layaknya sebuah pikiran yang kalut dan tidaksadar. Hanya saja di tengah situasi yang kalut dan tidaksadar inilah bahasa mengalami pembebasaannya sebagai bahasa. Bahasa bekerja kembali sebagai sesuatu yang "Ilahiah"; yang dapat mengekspresikan dirinya sendiri tanpa terlalu banyak ikut campur manusia yang memberikan tanda baca berupa titik (.), koma (,), hingga titik dua koma (;) sebagai jeda atas mobilitas bahasa.

Aliran ketidaksadaran sendiri merupakan kritik atas aliran kesadaran yang sudah mendominasi sejak masa Descartes (1596-1650), ketika Eropa mengalami perang agama yang memporakpandakan kehidupan (1560-1715), ketika para penjelajahnya menemukan wilayah baru di dunia, ketika ilmu-ilmu maju pesat. Itu semua membuat keyakinankeyakinan lama, khususnya agama, tergugat, goyah. Descartes, kita ingat, memulai filsafatnya dengan satu "keraguan yang radikal"; ia meragukan segala-galanya, termasuk pancaindra, tubuh, dan bahasanya sendiri. Dari sana ia terdorong mendapatkan kepastian yang tak bisa diragukan lagi. Dubito, ergo cogito, ergo sum. Pada posisi itu, sang subjek dianggap sepenuhnya sebuah kekuatan yang tak terganggu atau tercampuri perasaan ataupun oleh ruang di mana dia ada; ia tak terpaut dengan sebuah tubuh yang jadi bagian dari satu tempat di dunia. Dengan itu ia dianggap bisa menangkap dunia dengan "benar".

Dalam pada itu, ada satu ciri dalam dualisme Descartes. Kita ingat, epistemologi Cartesian dibangun dari dua sisi: di satu sisi ada "aku" yang berpikir, dan di sisi lain dunia yang dipikir; di satu sisi: res cogitans dan di sisi lain res extensa; di sisi sini subjek, dan di sisi sana: objek. Tapi dualisme itu hanya mengenal gerak satu arah: dari subjek ke objek, dan tak bisa sebaliknya. Akan tetapi Descartes sendiri tidak pernah bicara tentang bahasa. Descartes hanya membicaran posisi subjek di dunia yang diraguhkannya. Hanya saja apa dipikirkan oleh Descartes ini dimanfaatkan oleh beberapa tokoh filsafat untuk membangun konsep bahasa sebagai suatu kesadaran absolut. Martin Heidegger, adalah salah satu penganut aliran kesadaran ini. Heidegger meyakini bahwa bahasa adalah bagian dari "kesadaran-penuh" agar dirinya "Ada". Bahasa merupakan supremasi manusia untuk mengukuhkan dirinya di antara objek-objek di sekitarnya. Dengan kesadaran penuh berbahasa ini, manusia dapat menentukan, bahkan mengukur benda-benda tersebut sesuai dengan keinginannya. Kita dapat merasakan konsep kesadaran ini misalnya pada karyakarya lukis Jean Auguste Ingress (1780-1867) yang melukiskan perempuan-perempuan telanjang dalam Mandi Turki. Lukisan tersebut secara gambalang mengekang sebuah objek dengan sebuah lingkaran di tengah kanvasnya. Ingress seakan berusaha untuk mengurung objek-objeknya di dalam lukisan tersebut dengan kesadaranya. Berbeda sekali saat kita menikmati lukisan-lukisan Matta dalam Vertigo Eros (1944). Kanvas pelukis Surealis asal Cile ini termasuk dalam seri "Morfologi Kejiwaan" yang ia kerjakan pada 1940-an, ketika sang perupa menjelajah wilayah bawah-sadar dalam dirinya, melalui pembacaannya atas psikoanalisa Freud. 
Dalam karya prosa, kita dapat membaca karya-karya Albert Camus dalam aliran kesadaran ini. Novel Sampar adalah satu percobaan Camus dalam menerapkan aliran kesadaran ini. Camus menganggap Sampar adalah kritiknya terhadap kekacauan yang terjadi di tanah kelahirannya Aljazair. Dengan tokoh-tokoh yang digambarkan pantang menyerah dan menantang maut atas wabah penyakit yang melanda kota, Camus meletakan kesadaran sebagai bentuk perlawannya. Oleh sebab itu tidak aneh, Camus pernah menyatakan bahwa, "aku ada, maka aku berontak." Dalam peta sastra Indonesia, kita dapat mengenal nama Budi Darma dengan novelnya Orang-Orang Bloomongtion atau Olenka. Tokoh-tokoh Budi Darma yang sinis, tak mau mengalah, keji, dan kotor jiwanya, merupakan wujud dari bentuk kesadaran absolut suatu subjek yang dilakukan oleh Budi Darma. Sangat berbeda kiranya ketika kita membaca karya-karya Danarto atau beberapa cerpen Afrizal Malna yang suralis. Karya-karya mereka bekerja dengan sistem ketidaksadaran. Alur kisah-kisah mereka melompat-lompat layaknya sebuah 'kalimat yang mabuk,' bila meminjam kata Saut Sitomurong. Karya-karya dengan teknik narasi ketidaksadaran ini juga dapat kita rasakan pada karya William Flukner pada novelnya The Sound of Fury.

Aliran ketidaksadaran ini tentu adalah kritik atas modrenisme yang melahirkan aliran kesadaran yang dipelopori oleh Imanuel Kant hingga Descartes. Karena "kemajuan" yang diciptakan oleh modrenisme bergerak bersama kapitalisme yang melembagakan ketimpangan sosial, sikap individualisme, hingga nihilisme di dalam masyarakat. Kapitalisme mengubah "jiwa manusia" sebagai "jiwa teknologi” yang dapat dikalkulasikan dengan angka dan statistik. Dapat kita lihat, misalnya, selama pandemi ini, angka-angka di dalam statistik kasus masyarakat yang terpapar, sembuh, hingga meninggal dunia karena Covid-19. Mereka bukan lagi sebagai "jiwa manusia”, tetapi "jiwa teknologi” yang telah kehilangan kesadarannya. Kehilangan atas kesadaran ini adalah bagian dari kehilangan ketidaksadaran itu sendiri. Karena tidaksadar, manusia akan menjadi sadar. Demikian juga di dalam bahasa.

Dengan permainan teknik ketidaksadaran pada karya Rio Johan dan Eko Triono ini, sedikit memberikan kita kesadaran bahwa bahasa harus tetap elastis untuk merepsentasikan dirinya. Maka apa yang dilakukan oleh Rio Johan dan Eko Triono ini dapat kita sebuah pula sebagai "suatu ikhtiar" pembebasan bahasa dari kungkungannya-tentu apabila boleh saya meminjam kalimat dari generasi milenial, "menyebalkan dan ngeselin!".

\section{Daftar Pustaka}

[1] Adorno, Theodor. (1991). The Culture Industry: Selected Essays on mass Culture. New York and London: Routledge.

[2] Baudrillard, Jean. (1978). In the Shadow of the Silent Majorites. English and French: Les Cahiers d'Utopie.

[3] Brook, James \& Boal. (1996). Resisting Virtual Life: The Culture and Politics of Information. City Light. 
[4] Ahmad, Amar \& Nurhidayah. (2020). Media Sosial dan Tantangan Masa Depan Generasi Milenial, “Avant Garde: Jurnal Ilmiah Komunikasi, Vol. 08 No. 02, Desember.

[5] Marx, Karl. (2013). Capital. United Kingdom: Wordsworth Editions Ltd.

[6] Sunarto. (2001). Metode Penelitian Ilmu-ilmu Sosial dan Pendidikan. Surabaya: Unesa University Press.

[7] Oddang, Faisal. (2015). Puya ke Puya. Jakarta: KPG.

[8] Tony Bennett. (1981). Culture, Ideology, and Social Process, 1983. B T Batsford Ltd

[9] Eagleton, Terry. (2006). Criticism and Indeology: A Study in Marxist Literary Theory. Verso Book.

[10] Erlang, Niduparas . (2020). Burung Kayu. Teroka Press.

[11] Immanuel, Adimas. (2019). Di Hadapan Rahasia. Jakarta: Gramedia Pustaka.

[12] Benjamin, Walter. (1935). The Work of Art in Age of Mechanical Reproduction.

[13] Adorno, Theodor. (1951) Minima Moralia: Reflections from Damaged Life. Verso.

[14] Mohammad, Goenawan. (2012), Tatapan Jaka Tarub, Paper Ceramah Salihara.

[15] F Lawi, Mario. (2016). Mendengarkan Coldplay. Jakarta: Grasindo.

[16] Anugrah, Dea. (2016). Bakat Menggonggong. Yogyakarta: Buku Mojok.

[17] Habermas, Jurgen. (1985).The Philosophical Discorse of Modrenity. Germany: Suhrkamp Verlg.

[18] Mohammad, Goenawan. (2009). artikel Camus dan Kemajuan. Jakarta: Penerbit Alvabet.

[19] Setiadi, Tia. (2016). A Poetics of Surprise: Ikhtiar Memasuki Cerita Eko Triono. Yogyakarta: Diva Press.

[20] Triono, Eko. (2016). Agama Apa yang Pantas Bagi Pohon-Pohon. Yogyakarta: Diva Press.

[21] Johan, Rio. (2017). Ibu Susu. Jakarta: KPG.

[22] Baars, Subjektive Experience is Probably not Limmited to Humans the Evidence from Neourology. 